\title{
Large liquefaction of lymph nodes during tuberculosis-associated immune reconstitution inflammatory syndrome in an HIV-infected woman
}

\author{
${ }^{1}$ Hospices Civils de Lyon, Service de Maladies Infectieuses et Tropicales, Lyon, France \\ 2Université Claude Bernard Lyon 1, Lyon, France \\ ${ }^{3}$ INSERM U851, Pathogénie Bactérienne et Immunité Innée, Lyon, France
}

Magali Offner, ${ }^{1}$ Thomas Perpoint, $^{1}$ Christian Chidiac, ${ }^{1,2,3}$ Tristan Ferry $^{1,2,3}$

Correspondence to Dr Tristan Ferry, tristan.ferry@univ-lyon1.fr

\section{DESCRIPTION}

A 27-year-old HIV-positive untreated woman was admitted for general deterioration, fever, productive cough and peripheral lymph nodes. HIV viral load was $3.1 \times 10^{6}$ copies $/ \mathrm{ml}$ and CD4 cell count was 30 cells $/ \mathrm{mm}^{3}$. CT scan showed a nodule in the right upper pulmonary lobe, multiple cervical, intrathoracic, abdominal and inguinal lymph nodes. Disseminated tuberculosis (TB) was diagnosed as sputum cultures were positive for fully susceptible Mycobacterium tuberculosis. Rifampin, isoniazid, ethambutol and pyrazinamid were begun. Six weeks later, a well evolution permitted the introduction of antiretroviral therapy (ART). After 2 weeks, the patient presented with recurrent fever and convulsion. Imaging showed increase of the cerebral lesion with oedema. HIV viral load decreased by half and CD4 cell count rose at 93 cells/7 litre. TB-associated immune reconstitution inflammatory syndrome (IRIS) was mentioned and steroids (methylprednisolone, $0.5 \mathrm{mg} / \mathrm{kg}$ ) was begun with good results. Three months later, the patient presented with large enlargement and liquefaction of cervical lymph nodes leading to dysphagia (figure 1). After 18 months of antituberculous therapy associated with ART, the outcome was favourable, without surgical resection of the lymph nodes.

IRIS could occur in various situations after the start of highly active antiretroviral therapy (HAART). Paradoxical
TB-associated IRIS occurs in $8-43 \%$ of patients after the sequential introduction of anti-TB drugs and ART, and correspond to worsening symptoms of TB. ${ }^{1}{ }^{2}$ TB-IRIS is more frequently seen in patients with low CD4 count, high HIV viral load, disseminated TB at diagnosis and rapid reduction in viral load on $\mathrm{ART}^{2}{ }^{3}$ Management includes the continuation of TB-treatment and ART, associated with steroids. ${ }^{2}{ }^{4}$ Enlarging cervical lymph nodes are a common feature of paradoxical TB-IRIS but their liquefaction is rarely described; and might occur during steroid therapy, as described here. Surgery might not be performed, except for exceptional refractory cases with organ compression, only. ${ }^{24}$

\section{Learning points}

- Tuberculosis (TB)-associated immune reconstitution inflammatory syndrome (IRIS) could be associated with large liquefaction of lymph nodes.

- Management of TB-associated IRIS includes continuation of anti-TB drugs and HAART.

- Steroids might improve the morbidity of TB-associated IRIS, but surgery might not be performed, except for exceptional refractory cases with organ compression, only.

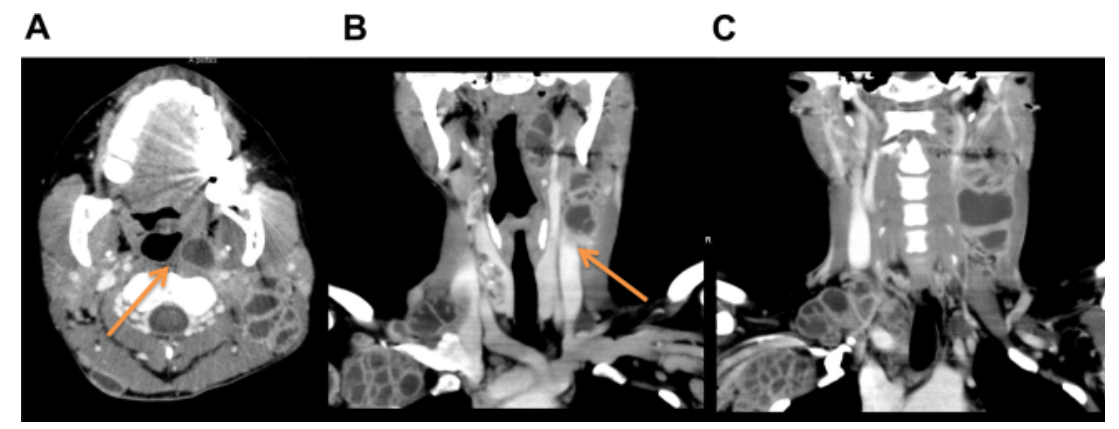

Figure 1 Axial CT scan (panel A) with coronal reconstructions (panels B and C) showing large liquefaction of cervical lymph nodes close to cervical vessels (arrow, panel B) with mass effect and cavum deformation (arrow, panel A). 


\section{BMJ Case Reports}

\section{Competing interests None.}

\section{Patient consent Obtained.}

\section{REFERENCES}

1. Sharma SK, Soneja M. HIV and immune reconstitution inflammatory syndrome (IRIS). Indian J Med Res 2011;134:866-77.

2. Dhasmana DJ, Dheda K, Ravn $\mathrm{P}$, et al. Immune reconstitution inflammatory syndrome in HIV-infected patients receiving antiretroviral therapy.
Pathogenesis, clinical manifestations and management. Drugs 2008;68:191-208.

3. Shelburne S, Visnegarwala F, Darcourt J, et al. Incidence and risk factors for immune reconstitution inflammatory syndrome during highly active antiretroviral therapy. AIDS 2005;19:399-406.

4. Marais S, Wilkinson RJ, Pepper DJ, et al. Management of patients with the immune reconstitution inflammatory syndrome. Curr HIV/AIDS 2009;6:162-71.

This pdf has been created automatically from the final edited text and images.

Copyright 2012 BMJ Publishing Group. All rights reserved. For permission to reuse any of this content visit http://group.bmj.com/group/rights-licensing/permissions.

BMJ Case Report Fellows may re-use this article for personal use and teaching without any further permission.

Please cite this article as follows (you will need to access the article online to obtain the date of publication).

Offner M, Perpoint T, Chidiac C, Ferry T. Large liquefaction of lymph nodes during tuberculosis-associated immune reconstitution inflammatory syndrome in an HIV-infected woman. BMJ Case Reports 2012;10.1136/bcr-2012-006652, Published XXX

Become a Fellow of BMJ Case Reports today and you can:

- Submit as many cases as you like

- Enjoy fast sympathetic peer review and rapid publication of accepted articles

- Access all the published articles

- Re-use any of the published material for personal use and teaching without further permission

For information on Institutional Fellowships contact consortiasales@bmjgroup.com

Visit casereports.bmj.com for more articles like this and to become a Fellow 